\title{
PROMOTING CREATORS INTENTIONS: MEASUREMENT OF CROWDFUNDING PERFORMANCE
}

\author{
Sentot Imam Wahjono* \\ Faculty of Economics and Business, Universitas Muhammadiyah Surabaya \\ Soo-Fen Fam \\ Faculty of Technology Management and Technopreneurship, Universiti \\ Teknikal Malaysia Melaka \\ Mukhaer Pakkanna \\ Faculty of Economics and Business, Institut Teknologi \& Bisnis Ahmad Dahlan \\ Ismail Rasulong \\ Faculty of Economics and Business, Universitas Muhammadiyah Makassar \\ Anna Marina \\ Faculty of Economics and Business, Universitas Muhammadiyah Surabaya
}

\begin{abstract}
Crowdfunding is an activity to collect small amounts of funds from a large audience via the internet without involving a financing intermediary. This study aims to determine the effect of fundraising, product testing, relationship reliability, and awareness-raising on the performance of the crowdfunding platform as an alternative source of business or business funding. This research was conducted using a quantitative approach, where Google forms were distributed to 267 project proponents, owners, or administrators in ASEAN countries as a sample and 197 sets of questionnaires were returned with complete answers and further analyzed. The data analysis used includes descriptive analysis, Pearson correlation, and multiple linear regression analysis. The results of this study indicate that all independent variables, namely the creator's intention in the form of fundraising, product testing, relationship reliability, and awareness-raising, have a positive and significant influence on the performance of the crowdfunding platform. This has practical implications that the creator's intention must be a concern for project proponents and fund owners who invest or distribute their funds in addition to paying attention to the business proposal and the reliability of the crowdfunding platform operator.
\end{abstract}

Keywords: Creators Intention, Crowdfunding Performance, Financing Intermediaries, Small Contribution

Received: 29 July 2019

Accepted: 10 May 2021

https://doi.org/10.33736/ijbs.4285.2021

\footnotetext{
* Corresponding author: Faculty of Economics and Business, Universitas Muhammadiyah Surabaya, Jl. Sutorejo 59, Surabaya 60113, Indonesia; Email: sentot.imamw@fe.um-surabaya.ac.id
} 


\section{INTRODUCTION}

Finance is an important resource needed to determine the success of employers (Liu et al., 2015). According to Tanrisever and Wismans-Voorbraak (2016), after the recent financial crisis, banks tend to be reluctant to provide funding to employers. Due to high market and technological risks, banks are even more reluctant to finance technology projects and technology-based startups. Therefore, entrepreneurs seek alternative ways to fund their businesses. Crowdfunding became an emerging resource to help entrepreneurs in fundraising (Cassar, 2014). Currently, several crowdbuilding projects have already reached various aspects of urban development. Crowd-funding changes people's perceptions and creates something between physical development and the provision of funds. In the city of Bogota, Colombia, a skyscraper worthy of the US \$ 170 million, is built right in the heart of the capital. All funds for the construction of these buildings have been collected from more than 300,000 residents of Bogota (Care et al., 2018). Crowdfunding has become popular as a successful alternative to community fundraising practices rather than traditional funding. There are 4 main models in crowdfunding. The first is donation-based Crowdfunding. The second is reward-based crowdfunding. The third is lending-based crowdfunding. The fourth is equity-based crowdfunding. Here is a list of sites that have different models and focuses: 1) Kickstarter, 2) Indiegogo, 3) Crowdfunder, 4) RocketHub, 5) Crowdrise, 6) Somolend, 7) appbackr, 8) AngelList, 9) Invested. in, 10) Quirky.

According to Liu et al. (2015), crowdfunding can be defined as an alternative way of funding from many people, although each in a small amount to run a business or project for a profit-oriented business or to finance charitable activities that are not intended to be profitable. It is an escape from the dependence of business financing on traditional financing sources such as banks. The definition implies an open call to anyone, a private person with a small funding capacity or an economic agency with a massive funding ability to grapple and jointly fund projects that range from innovative creative new projects to non-profit charity activities (Neville et al., 2014).

Projects, products, or ideas can be realized with the help of a group of people, who support them financially by contributing a small amount of capital. This alternative fund-raising activity is conducted by a crowdfunding operator who has an internet-based organization to connect project initiators or activities with fund owners. They will meet virtually on a crowdfunding platform. In a crowdfunding platform, operators will facilitate communication between project initiators and fund owners or investors or debtors in the form of uploading business proposals or activities and any information to run the business or new activities including prizes, fees or benefits, dividends, and benefits that an initiator may initiate projects to fund owners who contribute to supporting such projects or activities (Wahjono et al., 2015). However, these projects, products, or ideas are still owned by fundraisers and initiators of projects or activities.

The more virtual attention project initiators can gain, the more successful the project can be. Fundraising activities using a crowdfunding platform are commonly called fundraising. There are several examples of successful crowdfunding products that have been widely accepted and widely accepted and then mass-produced into manufactured products such as the Apple watch (Mollick \& Kuppuswamy, 2014). Fund-raising is not the sole purpose of initiating projects, activities, employers, or companies, it is also used in combination with other schemes such as getting the fund owners into the company as shareholders (Walthoff-Borm et al., 2018). 
Project initiators are also utilizing crowdfunding platforms to knowing the reception of products by the public (Lagazio \& Querci, 2018). The activity of identifying the community's response to the product of a project facilitated by a crowdfunding platform is often referred to as product testing. Another objective of someone participating actively in the crowdfunding platform is to get real information directly from business actors or directly from the owner of the fund (Viotto da Cruz, 2018). Fund owners can also read the development of funded business ventures and provide input for business improvement so that they can avoid bankruptcy (Jenkins et al., 2014). Information from both sides will strengthen good and solid relationships to maintain the reliability of mutually respectful and mutually beneficial relationships This activity is called relationship reliability.

Crowdfunding a good platform can also serve to provide enough information to prevent entrepreneurship startups from failure (Cassar, 2014). Sufficient information gained from crowdfunding platforms will shape awareness-raising. This study wanted to see the relationship of creator intentions consisting of fundraising, product testing, relationship reliability, and awarenessraising with successful crowdfunding.

\section{LITERATURE REVIEW}

Most start-up businesses require large funding, therefore they will usually face problems in obtaining funding, especially for entrepreneurs with new fields and types of business. On the other hand, traditional banks and financial institutions are accustomed to fund distribution mechanisms that apply several criteria for accepting credit proposals including being bank-able which is not friendly for new entrepreneurs with new types of business, especially during the economic crisis due to the virus pandemic. Business startup entrepreneurs also face difficulties because banks and angel investors need to evaluate their financial statements before making loans to them. Therefore, crowdfunding has become a popular tool to raise funds to ensure smooth realization of planned projects. Every year, crowdfunding plays a more significant role in the formation of new businesses and this can be proven by the continuously growing number of new crowdfunding platforms and new users. For those who have good planning even with less than sufficient funding support, crowdfunding may be one of their options to raise money to fund their business. Therefore, the crowdfunding platform is an alternative to get funding and fundraising.

The study of crowdfunding has become a major trend in recent years although it is nothing new internationally. According to Viotto da Cruz (2018), crowdfunding has been the backbone of the American political system for a long time. Every year, crowdfunding plays a more important role in distributing opportunities to entrepreneurs who want to run their projects and test products but without sufficient funding. Crowdfunding is an electronic platform that determines the funding costs for entrepreneurs and the returns investors will receive per period (Moritz \& Block, 2016). It is implemented by many countries such as China, USA, and UK.

Crowdfunding allows project proponents to propagate or promote their new business project or business development or business startup idea via the internet as a way of finding new funding for people to raise money to start their business or solve their financial problems. As we know, the internet is widely used by people nowadays and it allows people to spread the news virtually without any geographical boundaries. As a result, crowdfunding is becoming an efficient and wise option for people to raise money. This can be a competitive advantage when compared to 
traditional lending methods as it not only allows the project proponent to raise sufficient capital but also makes people aware of the product or service they will provide. The immediate increase in the use of crowdfunding platforms indicates an immediate increase in the popularity of the platform, which allows entrepreneurs to easily raise funds to start their businesses or settle their debts. Thus, crowdfunding can be used as a medium to foster reliable relationships between project proponents and fund owners.

The importance of various crowdfunding models as financing tools has been demonstrated by their marked growth in recent years. Several studies focusing on the motivation of funders in crowdfunding have been revealed, such as in the findings of Moritz and Block (2016) and Lagazio and Querci (2018). However, there has not been adequate research on the motivations of initiators of new business projects or startups. Lack of research on project proponent motivations will hinder a comprehensive understanding of crowdfunding, crowdfunding features, growth, and advantages of crowdfunding for project proponents compared to other funding sources. So, the important point of this research is to make people aware about crowdfunding and help people understand the advantages of crowdfunding so that they can take advantage of crowdfunding to achieve success in the funding market. In addition, it is important to know the dominant determinants that will influence people's decisions to choose crowdfunding over other funding sources, and awarenessraising.

Based on the information obtained from the sources, the researcher wants to test whether creators' intention in fundraising, product testing, relationship reliability, and awareness-raising can influence crowdfunding performances? Thus the theoretical framework for this research is as shown in Figure 1.

Figure 1: Theoretical Framework

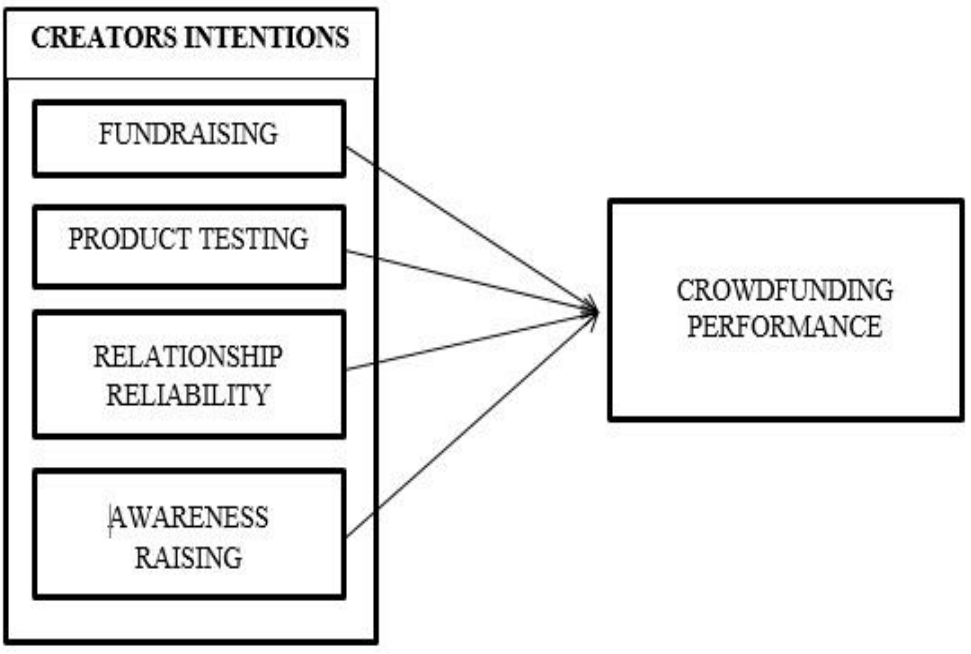


Based on the research background discussed above, the hypothesis that is tested in the study is shown as below:

H1: Fundraising has a significant relationship with crowdfunding performance as an alternative source of business funding.

H2: Product testing has a significant relationship with crowdfunding performance as an alternative source of funding.

\section{H3: Relationship reliability has a significant relationship with crowdfunding} performance as an alternative source of funding.

\section{H4: Awareness raising has a significant relationship with crowdfunding performance as an alternative source of funding.}

\section{METHODOLOGY}

This study uses a quantitative approach, using Google-Forms, an online survey service, to send questionnaires to respondents. This approach was chosen because crowdfunding is an online platform that integrates people from different places with flexible time. In addition, Google form can save time used for validating each questionnaire. There are 5 sets of question constructs to answer this research question: Fundraising consists of 5 questions, Product testing in 5 questions, Relationship Reliability in 6 questions, Awareness raising 6 questions, and Crowdfunding performance 10 questions. All questions are provided with closed answers with 4 choices of answers: Strongly-disagree (SA), Disagree (D), Agree (A), and Strongly-agree (SA).

\section{Population and Sample}

The population of this study consists of project initiators who are incorporated as members of several crowdfunding communities in Asia, particularly in ASEAN as shown in Table 1 on population and sample. Based on information tracking on Facebook, 6 Facebook communities can answer research questions and represent the unit of analysis: CF Asia, mystarts, Indonesian Crowdfunding, Crowdfunding Thailand, Crowdfunding Singapore, and Crowdfunding Vietnam.

Table 1: Population and Sample

\begin{tabular}{lrrrc}
\hline \hline \multicolumn{1}{c}{ CF Community } & Member & Sample & Complete & $\begin{array}{c}\text { Response } \\
\text { rate }\end{array}$ \\
\hline CF Asia & 6,947 & 100 & 53 & $53 \%$ \\
mystarts & 8,417 & 100 & 37 & $37 \%$ \\
Indonesia Crowdfunding & 509 & 75 & 45 & $60 \%$ \\
Crowdfunding Thailand & 289 & 50 & 26 & $52 \%$ \\
Crowdfunding Singapore & 73 & 25 & 20 & $80 \%$ \\
Crowdfunding Vietnam & 240 & 27 & 16 & $59 \%$ \\
\hline
\end{tabular}

The key questions about the position as a project initiator and citizen of ASEAN countries were asked to screen respondents because of the scope limitation of this study. As many as 16,475 
designated members of the population of this study were derived from members of 6 crowdfunding communities as in table 1. Based on the formula Krejcie and Morgan (1970) the number of samples was determined through purposive random sampling to be 377 . As many as 500 sets of questionnaires were sent to prospective respondents via Google Form and returned with complete answers that are ready to be analyzed as much as 197 , which means that the response rate is $52 \%$.

There are challenges during the distribution of questionnaires, namely the regulation of FaceBook that can only send no more than 50 direct messages per day. In addition, respondents were very busy answering questionnaires given their position as project initiators who were often busy with an initiated project campaign to get funding through equity-based crowdfunding.

\section{RESULTS AND DISCUSSION}

Based on Table 2, a majority of the respondents are male project initiators, comprising $64 \%$ of all, and female project initiators comprise $36 \%$ of all. The largest group of respondents, comprising 78 respondents (or 39.6\%) is in the age range of 35-44 years old. In terms of citizenship, a majority of the respondents come from Indonesia consisting of 59 respondents $(29.9 \%)$ and then from Malaysia (46 respondents), Singapore (24.4\%), and Thailand 36 respondents $(18.3 \%)$. In terms of education level, 85 respondents $(48.1 \%$ ) belong to undergraduate qualifications, followed by 78 respondents $(39.6 \%)$ qualify postgraduate. Then, there were 30 respondents $(15.2 \%)$ whose education level is secondary school. The CF Asia and mystarts community are international crowdfunding communities where citizens of several countries come together. The number of respondents with Indonesian citizenship in the communities is 59, 45 respondents from the Crowdfunding Indonesia community and the remaining 14 from CF Asia and mystarts. As for the citizens of Singapore, 20 people are from the Crowdfunding Singapore community while the remaining 28 are from the Asian CF community and mystarts. Meanwhile, the 46 Malaysian respondents, came from the Asian CF Community and mystarts. Similarly, the 26 Thailand respondents, are from the Crowdfunding Thailand community and 10 people are from the CF Asia community.

Table 2: Respondents' Demographic

\begin{tabular}{llcc}
\hline \hline & & $\mathbf{N}$ & Percentage \\
\hline Gender & Male & 126 & 64.0 \\
& Female & 71 & 36.0 \\
\hline Age & $18-24$ years old & 16 & 8.1 \\
& $25-34$ & 65 & 33.0 \\
& $35-44$ & 78 & 39.6 \\
& $45-54$ & 27 & 13.7 \\
& $>55$ & 11 & 5.6 \\
\hline Citizenship & Indonesia & 59 & 29.9 \\
& Malaysia & 46 & 23.4 \\
& Singapore & 48 & 24.4 \\
& Thailand & 36 & 18.3 \\
& Others & 8 & 4.1 \\
\hline Education Level & Primary School & 3 & 1.5 \\
& Secondary School & 30 & 15.2
\end{tabular}




\begin{tabular}{llcc}
\hline \hline & N & Percentage \\
\hline & Undergraduate & 85 & 48.1 \\
& Postgraduate & 78 & 39.6 \\
& Others & 1 & 0.5 \\
\hline Occupation & Government Sector & 11 & 5.6 \\
& Private Sector & 100 & 50.8 \\
& Self-Employed & 83 & 42.1 \\
& Others & 3 & 1.5 \\
\hline Self-Employed & Manufacturing & 14 & 16.9 \\
& Service & 18 & 21.7 \\
& Retail & 40 & 48.2 \\
& Others & 11 & 13.3 \\
\hline Working Experience & Below 10 years & 94 & 42.9 \\
& $10-20$ & 76 & 34.7 \\
& $21-30$ & 36 & 16.4 \\
& 31-40 & 13 & 5.9 \\
\hline Platform Used & Crowdo & 76 & 38.6 \\
& FundedHere & 19 & 9.6 \\
& MoolahSense & 29 & 14.7 \\
& PitchIn & 26 & 13.2 \\
& FundedByMe & 8 & 4.1 \\
& Funding Societies & 10 & 5.1 \\
& Others & 29 & 14.7 \\
\hline \hline & Once & 73 & 37.1 \\
Frequency Using & $2-5$ & 81 & 41.1 \\
& 6-10 & 27 & 13.7 \\
& 11 and Above & 16 & 8.1 \\
\hline
\end{tabular}

Then, there were 78 respondents $(39.6 \%)$ whose education level is postgraduate and the others consist of 30 respondents $(15.2 \%)$ from secondary school. For in term occupation, the respondents who work in private sectors are dominating, represented by 100 respondents $(50.8 \%)$ of the total sample size, those working in the service sector comprises 40 respondents $(48.2 \%)$ is at the top with 83 respondents who occupation is self-employed. The range of working experience of the respondents is $36.5 \% 10$ years, $38.6 \%$ between 10 - and 20 years, $18.3 \%$ of $21-30$ years, and $6.6 \%$ 0f 31-40 years. The platform that most respondents use is Crowdo which comprises 76 respondents (38.6\%). Most of the respondents participate 2-5 times in crowdfunding.

\section{Crowdfunding as a Fundraising}

The main purpose of crowdfunding is fundraising (Gerber et al., 2012). This research examines whether the statement is true. There are 5 questions to know the truth of the statement:

FR1 I used lending-based crowdfunding to gain money in a short time after the project is launched successfully

FR2 I used the crowdfunding platform as I can raise money in a democratic way

FR3 I used a lending-based crowdfunding platform as it provides an easy, efficient, organized way to solicit and collect financial support

FR4 I used a lending-based crowdfunding platform as it is useful when I was unable to get financial support from traditional funding sources

FR5 I used a lending-based crowdfunding platform as I can raise funds faster 
Table 3 shows respondents' opinions about crowdfunding function for fundraising. FR1, 77.1\% of respondents agreed or strongly agreed that they can gain money in a short time after they launched a successful project via crowdfunding. In FR2, 87.8\% of the respondents agreed or strongly agreed with the statement "I used the crowdfunding platform as I can democratically raise money". In FR3, $88.8 \%$ of respondents agree or strongly agree that they used the crowdfunding platform because of its easy, efficient, organized way to solicit and collect financial support. $91.4 \%$ of the respondents in FR4 agreed that the crowdfunding platform will become their option because it is useful when they are unable to get financial support from traditional funding sources. Lastly is FR5, $83.2 \%$ of the respondents agreed or strongly agreed that they use a crowdfunding platform as it can help them raise funds faster.

Table 3: Statistics for Fundraising

\begin{tabular}{lcccc}
\hline \hline \multirow{2}{*}{ Variables } & \multicolumn{4}{c}{ Frequencies (\%) } \\
\cline { 2 - 5 } & SD & D & A & SA \\
\hline FR1 & 13.2 & 9.6 & 22.3 & 54.8 \\
FR2 & 6.1 & 6.1 & 45.2 & 42.6 \\
FR3 & 4.1 & 7.1 & 53.3 & 35.5 \\
FR4 & 2.5 & 6.1 & 46.7 & 44.7 \\
FR5 & 6.1 & 10.7 & 34.5 & 48.7 \\
\hline \hline
\end{tabular}

The findings in the overall indicator in fundraising explain that crowdfunding facilitates the search for funds in crowds even in small numbers. This explains the findings of Walthoff-Borm et al. (2018) that crowdfunding is very beneficial to project initiators for funding including equity-based crowdfunding even as a last resort. In contrast, the findings of this research contradict the findings of Bouncken et al. (2015) who found evidence that the fashion industry in the UK found failure in obtaining funding through the crowdfunding platform. Failure of funding reached $81 \%$ although the fashion product designers have campaigned in an organized manner.

\section{Crowdfunding for Product testing}

Moritz and Block (2016) state that crowdfunding is a tool to test the product. This research examines whether the statement is true. There are 5 questions to know the truth of the statement:

PT1 I used a lending-based crowdfunding platform to interact with customers during product development so it will yield a high product success rate due to high market demand.

PT2 I used a lending-based crowdfunding platform to obtain customers' reviews about upcoming products.

PT3 I used a lending-based crowdfunding platform as it is easy to communicate with the target group

PT4 I used a lending-based crowdfunding platform so that I can hear the needs of the target group

PT5 I used a lending-based crowdfunding platform as I can explain specific features of my product to the potential customers

Table 4 reveals that the descriptive analysis results for the individual questions of the product testing variable. In PT1, 84.8\% of respondents agreed or strongly agreed that they yielded high 
product success when using the crowdfunding platform to interact with customers during product development. In PT2, respondents who were satisfied that they can get customers' reviews about upcoming products comprised up to $84.8 \%$. Then, $15.3 \%$ of the respondents disagreed with obtaining reviews from customers about upcoming products. For PT3, most of the respondents agreed or strongly agreed that the crowdfunding platform can make them communicate with the target group easily. The percentages of those agreeing and strongly agreeing are $37.1 \%$ and $51.3 \%$. In PT4, 83.3\% of the respondents who are agreed or strongly agreed that they can hear the needs of the target group via the crowdfunding platform. Lastly is PT5, 89.4\% of respondents stated that they agreed or strongly agreed with the statement "I used crowdfunding platform as I can explain specific features of my product to potential customers.

Table 4: Statistics of Product Testing

\begin{tabular}{lcccc}
\hline \hline \multirow{2}{*}{ Variables } & \multicolumn{3}{c}{ Frequencies $(\boldsymbol{\%})$} \\
\cline { 2 - 5 } & SD & D & A & SA \\
\hline PT1 & 5.1 & 10.2 & 37.6 & 47.2 \\
PT2 & 5.1 & 10.2 & 33.5 & 51.3 \\
PT3 & 3.6 & 8.1 & 37.1 & 51.3 \\
PT4 & 7.1 & 9.6 & 37.6 & 45.7 \\
PT5 & 3.6 & 7.1 & 43.7 & 45.7 \\
\hline \hline
\end{tabular}

Source: Data analysis of SPSS

The research findings on this Product testing corroborate Lagazio and Querci (2018) findings that crowdfunding platforms facilitate business projects including early and small-scale businesses as well as social and altruism projects as long as the project's campaign on a long-term basis. The findings of this research on Product testing by communicating products continuously to the group can easily improve business success. This is in line with the research findings of Sleuwaegen and Onkelinx (2014) who found evidence that crowdfunding increases commitment to progress and development. The findings from Belgian companies show an increase in exports including for startup companies and exporters of traditional commodities using crowdfunding.

\section{Crowdfunding for Relationship reliability}

Crowdfunding ensures relationship reliability (Tanrisever \& Wismans-Voorbraak, 2016). This research examines whether or not the statement is true. There are 6 questions to know the truth of the statement:

RR1 I used a lending-based crowdfunding platform so that I was able to contact the funders directly

RR2 I used a lending-based crowdfunding platform to build a longer-term connection with investors

RR3 I used a lending-based crowdfunding platform to collaborate with the funders directly blurring the role between producer and consumer

RR4 I used a lending-based crowdfunding platform because it can record supporters' contacts and provide online messaging services

RR5 I used a lending-based crowdfunding platform as it can build a fan base

RR6 I used a lending-based crowdfunding platform as the connections are not only for the supporters but also for other creators 
Table 5 shows that the descriptive analysis results for the individual questions of the relationship reliability variable. In RR1, a majority of respondents strongly agreed that they can contact the funder directly via the crowdfunding platform. The statements for agreeing and strongly agreeing are $34.0 \%$ and $53.8 \%$ respectively. In RR2, $89.4 \%$ of respondents agreed or strongly agreed to the statement "I used the crowdfunding platform to build a longer-term connection with investors". However, $10.7 \%$ of respondents disagreed or strongly disagreed with this statement. As for the RR3, 85.3\% of respondents agreed or strongly agreed that they use the crowdfunding platform to collaborate with the funder directly so that the role division between the producer and the consumer can be blurred. For RR4, most of the respondents agreed or strongly agreed that they used the crowdfunding platform because it can record supporters' contacts and provide online messaging services. The percentages for agreeing and strongly agreeing are $42.6 \%$ and $46.2 \%$ respectively. In RR5, respondents were satisfied that they used the crowdfunding platform because of building a fan base makeup to $90.8 \%$. Lastly for RR6, $93.9 \%$ of respondents agreed or strongly agreed that the connections were not only for the supporters but also for other creators.

Table 5: Statistics for Relationship Reliability

\begin{tabular}{lcccc}
\hline \hline \multirow{2}{*}{ Variables } & \multicolumn{4}{c}{ Frequencies (\%) } \\
\cline { 2 - 5 } & SD & D & A & SA \\
\hline RR1 & 5.6 & 6.6 & 34.0 & 53.8 \\
RR2 & 5.1 & 5.6 & 37.6 & 51.8 \\
RR3 & 6.6 & 8.1 & 38.1 & 47.2 \\
RR4 & 5.1 & 6.1 & 42.6 & 46.2 \\
RR5 & 4.1 & 5.1 & 41.6 & 49.2 \\
RR6 & 3.0 & 3.0 & 43.1 & 50.8 \\
\hline \hline
\end{tabular}

Source: Data analysis of SPSS

The RR1 finding that crowdfunding serves as an information mechanism because project initiators can have direct contact with funders is in line with the findings of Viotto da Cruz (2018) finding. With internet-based resources, project initiators may decide to release products in the market if their products are rated positive but less well received by funders. The findings of this research explain the findings of Jenkins et al. (2014) of how a company can avoid the risk of business failure by avoiding bankruptcy. With crowdfunding, project initiators can establish and develop relationships with funders for long periods.

\section{Crowdfunding for Awareness raising}

Crowdfunding has the potential to generate mutual awareness (Gerber et al., 2012). This research examines whether the statement is true. There are 6 questions to know the truth of the statement:

AR1 I used a lending-based crowdfunding platform as it shares my work publicly

AR2 I used lending based crowdfunding to expand my awareness through social media such as Facebook

AR3 I used lending based crowdfunding as it can influence my online profile such as increasing followers on Twitter

AR4 I used lending based crowdfunding as I can expand awareness by posting links to my project on social media and sending emails about my campaign to friends, family, and news media outlets 
AR5 I used lending based crowdfunding to raise awareness of people to whom I am not close

AR6 I used a lending-based crowdfunding platform as it allows me to spread the word about my work

Table 6 shows the results of descriptive analysis for individual questions to construct awareness variables. In AR1, 90.3\% of respondents agree or strongly agree that they can share their work publicly through a crowdfunding platform. In AR2, $90.4 \%$ of respondents agree or strongly agree that they can expand their awareness on social media such as Facebook through crowdfunding platforms. In AR3, 81.7\% of respondents agree or strongly agree that they use crowdfunding because it can affect their online profile such as increasing followers on Twitter. In AR4, 89.8\% of respondents agree or strongly agree that they use crowdfunding because they can raise awareness by linking links to their projects on social media, and also they can send emails about their campaigns to close family, relatives, coworkers, friends. schools, and news media both online and print media. In AR5, 91.4\% of respondents agreed or strongly agreed with the statement "I use credit-based crowdfunding to raise awareness of people who are not close to me". Lastly for ER6, 93.9\% of respondents agree or strongly agree that they use a crowdfunding platform because it can spread the word about their work.

Table 6: Statistics for Awareness Raising

\begin{tabular}{lcccc}
\hline \hline Variables & \multicolumn{4}{c}{ Frequencies (\%) } \\
\cline { 2 - 5 } & SD & D & A & SA \\
\hline AR1 & 2.5 & 7.1 & 35.0 & 55.3 \\
AR2 & 5.1 & 4.6 & 37.6 & 52.8 \\
AR3 & 8.1 & 10.2 & 41.1 & 40.6 \\
AR4 & 6.6 & 3.6 & 41.1 & 48.7 \\
AR5 & 4.1 & 4.6 & 34.5 & 56.9 \\
AR6 & 2.5 & 3.6 & 37.6 & 56.3 \\
\hline \hline
\end{tabular}

Source: Data analysis of SPSS

This finding answers Cassar's (2014) question about the failures of startup entrepreneurs who do business in high-tech industries. Such business failures can be avoided by fostering and increasing awareness among others by sharing their business experience with the public using crowdfunding platforms and also social media like Facebook, Twitter, and Whatsapps.

\section{Crowdfunding Performance}

Crowdfunding produces high performance when using the right technology and one can communicate efficiently (Zvilichovsky et al., 2015). This research examines whether the statement is true. There are 10 questions to know the truth of the statement:

CP1 The performance of the platform was high because it provided various communication tools such as discussion forums for project-based community

CP2 The performance of the platform was as high as it was facilitated by the technology so that the founder was able to create a video to present their project 
CP3 The performance of the platform was high because it allowed funders to leave comments on the owners' projects

CP4 The performance of the platform was as high as it was able to conversations between me and funders

CP5 The performance of the platform as high as the campaign webpage can update the funders' information during the campaign and also after it has ended

CP6 The performance of the platform as high as it provided easy-to-manage of all active campaigns listing in each category

CP7 The performance of the platform was as high as I could form a community that could extend the virtual communities outside the platform

CP8 The performance of the platform was as high as I could maintain user groups, internet forums, and websites that provide an update for the community regarding the trend of the product that I had provided

CP9 The performance of the platform as high as it maintained a blog, a Facebook page, and a newsletter to provide the community members with updates regarding the platform as well as to promote featured projects

CP10 The performance of the platform as high as my interests were the same as what the platform offered

Table 7 shows the result of a dependent variable for each question. For all the 10 items of crowdfunding performance, most of the respondents chose to strongly agree when they are requested to make decisions based on individual questions. In $\mathrm{CP} 1,90.8 \%$ of the respondents agreed or strongly agreed that the performance of crowdfunding is high because it provides various communication tools. In CP2, 92.9\% of the respondents agreed or strongly agreed that the performance of the platform is high due to the facilitation of technology. In CP3, 90.3\% of the respondents agreed or strongly agreed with the statement "The performance of platform was high because it allowed funders to leave comments on the owners' projects".

Table 7: Statistics for Crowdfunding Performance

\begin{tabular}{lcccc}
\hline Variables & \multicolumn{4}{c}{ Frequencies $\mathbf{( \% )}$} \\
\cline { 2 - 5 } & SD & D & A & SA \\
\hline CP1 & 2.0 & 7.1 & 41.1 & 49.7 \\
CP2 & 2.0 & 5.1 & 32.5 & 60.4 \\
CP3 & 2.5 & 7.1 & 41.6 & 48.7 \\
CP4 & 3.0 & 6.1 & 38.1 & 52.8 \\
CP5 & 2.5 & 5.6 & 33.0 & 58.9 \\
CP6 & 2.5 & 4.6 & 37.1 & 55.8 \\
CP7 & 4.1 & 5.6 & 38.6 & 51.8 \\
CP8 & 3.6 & 8.1 & 39.6 & 48.7 \\
CP9 & 3.0 & 10.7 & 39.6 & 46.7 \\
CP10 & 3.0 & 6.6 & 36.5 & 53.8 \\
\hline \hline
\end{tabular}

Source: Data analysis of SPSS

At CP4, 90.9\% of respondents agree or strongly agree that crowdfunding platform performance is high because it allows them to have conversations with funders. $91.9 \%$ of respondents in CP5 agree that crowdfunding platform performance is high because the portal and web pages used for 
business campaigns can update funder information during the campaign as well as after the campaign ends. For CP6, most respondents agree or strongly agree that such high crowdfunding performance provides easy-to-manage features for all active campaign lists in each category. The percentages of agree and strongly agree are $37.1 \%$ and $55.8 \%$, respectively. At CP7, 90.4\% of respondents agree or strongly agree that crowdfunding allows them to form communities that can extend virtual communities beyond the platform. At CP8, 88.3\% of respondents agree or strongly agree that crowdfunding allows them to maintain user groups, forums, and websites that update the community about the product trends I provide. At CP9, 86.3\% of respondents agreed or strongly agreed with the statement "High platform performance due to maintaining blogs, Facebook walls, Telegram pages, and newsletters to provide community members with updates and updates regarding the platform and to promote featured projects". Finally, CP10, 90.3\% of respondents agree or strongly agree that crowdfunding is useful because their interests are the same as what the platform offers.

\section{Hypothesis Test}

The research objective is to examine creators' intention that influences the crowdfunding performance to become an alternative source of business funding. The research framework theorizes that fundraising, product testing, relationship reliability, and awareness-raising. As the result, both research objectives have been achieved.

Table 8: Hypothesis Test Result

\begin{tabular}{|c|c|c|c|}
\hline Hypothesis & $\begin{array}{c}\text { Pearson' Correlation } \\
\text { Coefficients }\end{array}$ & Significant & $\begin{array}{l}\text { Hypothesis } \\
\text { Test Outcome }\end{array}$ \\
\hline $\begin{array}{l}\text { H1: Fundraising has a significant } \\
\text { Relationship with the performance of } \\
\text { crowdfunding platform as the } \\
\text { alternative source of funding. }\end{array}$ & 0.685 & 0.038 & Supported \\
\hline $\begin{array}{l}\text { H2: Product testing has a significant } \\
\text { relationship with the performance of } \\
\text { crowdfunding platform as an alternative } \\
\text { source of funding. }\end{array}$ & 0.628 & 0.006 & Supported \\
\hline $\begin{array}{l}\text { H3: Relationship reliability has } \\
\text { significant relationship with the } \\
\text { performance of crowdfunding platform } \\
\text { as an alternative source of funding. }\end{array}$ & 0.762 & 0.000 & Supported \\
\hline $\begin{array}{l}\text { H4: Awareness raising has significant } \\
\text { relationship with the performance of } \\
\text { crowdfunding platform as an alternative } \\
\text { source of funding. }\end{array}$ & 0.682 & 0.000 & Supported \\
\hline
\end{tabular}

H1: Fundraising has a significant relationship with the performance of crowdfunding platforms as an alternative source of funding. 
Pearson's coefficient of $\mathrm{r}=0.685>0.7$ means that there is a significant relationship between fundraising and the performance of crowdfunding. According to Gerber et al. (2012), the platform does not only provide a method to make payment collection online, but it also offers a process to accept a small payment from the crowd. In addition, they also are encouraged to participate in crowdfunding because it raises money in a democratic process. They are also encouraged to raise money which is consistent with their identity value. The result is also in line with Kovtun (2014) also line with Wahjono et al. (2018) which shows that the vital reason for motivating people to use crowdfunding is that it is a viable choice for getting funding. In addition, some of the creators use crowdfunding to ensure they can finance and run the initial stage of production.

Table 8 about hypothesis test result shown fundraising has a significant effect on crowdfunding performance to become an alternative source of funding which is p-value (0.038) lower than the significance level of 0.05. The hypothesis is supported. According to Gerber and Hui (2013), the platform does not only provide a method to make payment collection online, but it also offers a process to accept a small payment from the crowd. In addition, they also are encouraged to participate in crowdfunding because of raising money in a democratic process. They are also encouraged to raise money which is consistent with their identity value. The result is also in line with Borello et al. (2015) who shows that the vital reason to motivate people to use crowdfunding is that it is a viable choice to getting funding. In addition, some of the creators who use crowdfunding ensure they can finance and run the initial stage of production.

$\mathrm{H} 2$ : Product testing has a significant relationship to the performance of crowdfunding platforms as an alternative source of funding.

Pearson's coefficient of $r=0.628>0.7$ means there is a significant relationship between fundraising and the performance of crowdfunding. This can be explained by the fact that project owners who use crowdfunding can predict what change they can make to the product to increase the market's interest. This is because crowdfunding is a suitable platform that helps them to test a product by collecting a set of valuable data from future or potential buyers before the product is launched on the market. In addition, the entrepreneurs can also test their products demand by determining whether they can successfully raise target funding or not (Kovtun, 2014). This is in line with Mollick and Kuppuswamy (2014) who stated that the most satisfying answer for people to participate in crowdfunding is to test whether there is market demand.

Based on the data analysis, product testing also has a significant effect on crowdfunding performance to become an alternative source of funding which is p-value (0.006) below the significance level of 0.05 . The hypothesis is accepted. This can be explained by the fact that project owners who use crowdfunding can predict what change they can make to the product to increase its attractiveness to the market. This is because crowdfunding is a suitable platform that helps them to test the product by collecting a set of valuable data from future or potential buyers before the product is launched to the market. In addition, entrepreneurs can also test their product demand by determining whether they can successfully raise the target funding or not (Kshetri, 2018). This is in line with Mollick and Kuppuswamy (2014) who stated that the most satisfy-upon answer for people to participate in crowdfunding is to test whether there is market demand.

H3: Relationship reliability has a significant relationship with the performance of a crowdfunding platform as an alternative source of funding. 
Pearson's coefficient of $\mathrm{r}=0.762>0.7$ means there is a significant relationship between fundraising and the performance of crowdfunding. Based on Gerber et al. (2012), creators are encouraged to involve in crowdfunding as they can build a connection directly through a long-term interaction. The long-term interaction allows the collaboration happening between creators and funders, the border between the producer and consumer also can be blurred. The same result is also gets from Gerber and Hui (2013). They show that the people who are using crowdfunding are not only for that single financial transaction, but they are also interested in information about long-term interaction with the crowd. Crowdfunding can accelerate the way to form a connection with potential or future supporters as supporters' contact information will be stored and also the service of online messaging is provided. Creators also can answer the uncertainty problem of the supporter or update the information of the project so that it can increase supporters' confidence level toward their projects and hence a good relationship can be established. They can also make a connection to other creators so that the process of exchanging knowledge and experience can happen.

According to the data analysis, it is found that relationship reliability has a significant impact on crowdfunding performance as an alternative source of funding, as we can see from the p-value (0.000) that is greater than the significant level of 0.05. Therefore, the hypothesis is supported. Based on Gerber et al. (2012), creators are encouraged to involve in crowdfunding as they can build a connection directly through a long-term interaction. The long-term interaction allows collaboration happening between creators and funders, the character between producer and consumer also can be blurred. The same result also is get from Gerber and Hui (2013). They show that the people who are using crowdfunding are not only for that single financial transaction, but they are also interested in information from a long-term interaction with the crowd. Crowdfunding can accelerate the way to form a connection with potential or future supporters as the contacts of supporters will be stored and also the service of online messaging is provided. Creators also can answer the uncertainty problem of the supporters or update the information of the project so that it can increase the confidence level of the supporters toward their projects and hence a good relationship can be established. They also can make the connection to other creators so that the process of exchanging knowledge and experience can happen (Wahjono et al., 2020).

H4: Awareness raising has a significant relationship with the performance of crowdfunding platforms as an alternative source of funding.

The Pearson's coefficient of $r=0.682>0.7$ means there is a significant relationship between fundraising and the performance of crowdfunding. Based on the research study by the researcher (Wahjono et al., 2019; Gerber et al., 2012; Kovtun, 2014), project initiators are encouraged to join in crowdfunding because their awareness can be expanded through social media. Besides their work can be communicated online, the spreading of the work also can be confirmed by monetary gifts. It can also be a very attractive marketing source to expand creators' awareness. This is because viral marketing initiated by supporters takes place and helps establish customers' communities as marketers, multi-directional communication between the projects and the backers can be formed and also can attract attention from the media.

Based on the data analysis, it was also found that awareness-raising has a significant impact on crowdfunding performance as an alternative source of funding whit the p-value $(0.000)$ greater than the significant level of 0.05 . Hence, the hypothesis is accepted. Based on the research study 
by the researcher (Gerber et al., 2012; Forbes \& Schaefer, 2017), project initiators were encouraged to join in crowdfunding because their awareness can be expanded via social media. In addition to the advantage of being able to communicate their work online, the spreading of the work also can be confirmed by monetary gifts. It also can be a very attractive marketing source to expand creators' awareness. This is because viral marketing initiated by the supporters takes place and, helps establish customers' communities as marketers, multi-directional communication between the projects and the backers can be formed and also can attract attention from the media.

\section{CONCLUSION}

The study determines creators' intention to use crowdfunding platforms as an alternative source of business funding. Fundraising, product testing, relationship reliability, and awareness-raising significantly influence crowdfunding performance. This research study has achieved its purpose by investigating the relationships of independent variables and dependent variables relationship. Due to some of the limitations are faced while conducting during conducting the research, some of the recommendations regarding these limitations were also discussed. In short, the research can provide insight for future research regarding this topic. Crowdfunding can be an alternative source of business funding and it is very useful especially for start-up ventures. Although crowdfunding is still not widespread in ASEAN countries, the crowdfunding platform owners are trying to use a different method to improve the awareness in the society and this includes giving a talk or utilizing social media to transfer the crowdfunding knowledge to the public. To protect the right of the crowd and the project initiators, governments of ASEAN countries need to develop a rule to minimize the risk of fraud. The implication of this study shows that crowdfunding is not only providing financial benefits but at the same time also provides non-financial benefits. This is very useful especially for start-up businesses that wish to overcome their financial problems and also to extend their network distribution well. The level of confidence towards people who intend to start their business will also be increased. This is important because once there are a lot of start-up businesses, job vacancies will increase and the economy of a country will also increase.

There are some recommendations to solve the limitations of the study and improve future research studies. First researchers should increase the size of the sample and population as much as possible to enhance result accuracy and also the reliability of independent variables and dependent variables. Besides, a deeper analysis of motivation can also be discussed in future studies. In addition, future studies can focus on the size of creators' social networks, creators' expertise, types of projects they launch, and funding level because these can also affect participants' motivation.

\section{ACKNOWLEDGEMENT}

Thanks to the Ministry of Education and Culture, Research, and Higher Education, the Republic of Indonesia for funding this research. 


\section{REFERENCES}

Borello, G., De Crescenzo, V., \& Pichler, F. (2015). The funding gap and the role of financial return crowdfunding: Some evidence from European platforms. Journal of Internet Banking and Commerce, 20(1), 1-20.

Bouncken, R. B., Komorek, M., \& Kraus, S. (2015). Crowdfunding: The current state of research. The International Business \& Economics Research Journal, 14(3), 407.

Care, S., Trotta, A., Care, R., \& Rizzello, A. (2018). Crowdfunding for the development of smart cities. Business Horizons, 61(4), 501-509.

Cassar, G. (2014). Industry and startup experience on entrepreneur forecast performance in new firms. Journal of Business Venturing, 29(1), 137-151.

Forbes, H., \& Schaefer, D. (2017). Guidelines for Successful Crowdfunding. Procedia CIRP, 60(2017), 398-403.

Gerber, E., Hui, J., \& Kuo, P. (2012). Crowdfunding: Why people are motivated to post and fund projects on crowdfunding platforms. Retrieved November 23, 2021, from https://cpb-use1.wpmucdn.com/sites.northwestern.edu/dist/3/3481/files/2012/11/Gerber_Crowdfundin g_MotivationsandDeterrents.pdf

Gerber, E. M., \& Hui, J. (2013). Crowdfunding: Motivations and deterrents for participation. ACM Transactions on Computer-Human Interaction (TOCHI), 20(6), 1-32.

Jenkins, A. S., Wiklund, J., Brundin, E. (2014). Individual responses to firm failure: Appraisals, grief, and the influence of prior failure experience. Journal of Business Venturing, 29(1). 17-33.

Kshetri, N. (2018). Informal Institutions and Internet-based Equity Crowdfunding. Journal of International Management, 24(1), 33-51.

Kovtun, D. (2014). Implementation and Marketing for a Successful Crowdfunding Campaign Case: $X$-routes [Bachelor's thesis, University of Applied Science]. Theseus. http://urn.fi/URN:NBN:fi:amk-2014120818900

Krejcie, R. V., \& Morgan, D. W. (1970). Determining Sample Size for Research Activities. Educational and Psychological Measurement, 30, 607-610.

Lagazio, C., \& Querci, F. (2018). Exploring the multi-sided nature of crowdfunding campaign success. Journal of Business Research, 90, 318-324.

Liu, N., Xiang, L., Liu, X. (2015). Research on equity-based crowdfunding based on corporate finance theory. 2015 International Conference on Behavioral, Economic and Sociocultural Computing (BESC 2015). Nanjing, China.

Mollick, E. R., \& Kuppuswamy, V. (2014). After the campaign: Outcomes of crowdfunding. (UNC Kenan-Flagler Research Paper No. 2376997). https://doi.org/10.2139/ssrn.2376997

Moritz, A., \& Block, J. H. (2016). Crowdfunding: A literature review and research directions. In D. Bruntje \& O, Gajda (Eds.), Crowdfunding in Europe: State of the Art in Theory and Practice (pp. 25-53). Springer International Publishing

Neville, F., Orser, B., Riding, A., \& Jung, O. (2014). Do young firms owned by recent immigrants outperform other young firms? Journal of Business Venturing, 29(1), 55-71.

Sleuwaegen, L., \& Onkelinx, J. (2014). International commitment, post-entry growth, and survival of international new ventures. Journal of Business Venturing, 29(1), 106-120.

Tanrisever, F., \& Wismans-Voorbraak, K. A. (2016). Crowdfunding for Financing Wearable Technologies. Proceedings of the 2016 49th Hawaii International Conference on System Sciences (HICSS) (pp. 1800-1807). Washington, DC, United States. 
Viotto da Cruz, J. (2018). Beyond financing: crowdfunding as an informational mechanism. Journal of Business Venturing, 33(3), 371-393. https://doi.org/10.1016/j.jbusvent.2018.02.001

Wahjono, S. I., Marina, A., \& Fikry, M. (2015). Innovative funding solution for special projects: Crowdfunding. Journal of Economics, Business \& Accountancy Ventura, 18(1), 65-74.

Wahjono, S. I., Marina, A., Fam, S. F., \& Hasan, A. (2020). Equity-Based Crowdfunding Project: Affect on Social Capital. Advances in Business Research International Journal, 6(1), 5058 .

Wahjono, S. I., Marina, A., Oceano, P. M. N. R., \& Fam, S. F. (2018). Readiness of Crowdfunding to Finance Small and Medium-Sized Enterprises in ASEAN. The Social Sciences, 13(3), 657 - 663. https://doi.org/10.36478/sscience.2018.657.663

Wahjono, S. I., Marina, A., Sezeli, S. S., \& Mahardhika, B. W. (2019). The Role of social awareness over the Success of Crowdfunding Platform. Humanities and Social Sciences Reviews, 7(3), 534-540.

Walthoff-Borm, X., Schwienbacher, A., \& Vanacker, T. (2018). Equity crowdfunding: First resort or last resort? Journal of Business Venturing, 33(4), 513-533.

Zvilichovsky, D., Inbar, Y., \& Barzilay, O. (2015). Playing both sides of the market: Success and reciprocity on crowdfunding platforms. SSRN Electronic Journal, https://doi.org/10.2139/ssrn.2304101 